Vantage: Journal of Thematic Analysis

ISSN: 2582-7391

A Multidisciplinary Publication of Centre for Research, Maitreyi College, University of Delhi

October 2020, Volume 1, Issue 2

Original Research Article

\title{
Crimes in the Time of COVID-19
}

\author{
Priti Mendiratta Arora*, Ruchika Rao and Sanskriti Agrawal
}

Department of Economics, Maitreyi College, Chanakyapuri, New-Delhi-110021

*Correspondence: parora@maitreyi.du.ac.in

\begin{abstract}
Due to the current pandemic, governments all over the world have given stay at home orders and have advised people to follow precautions like social distancing. These measures have a significant impact on our social, economic, and political setting which ultimately affects the volume and distribution of crimes worldwide. To understand the impact of social distancing policies on crime, we have compared the crime statistics during the pandemic (2020) with that of the previous year (2019) for the two metropolitan cities New Delhi, India, and New York, USA. We observe the trends of different types of crime and conclude that while crimes like residential burglaries have reduced, crimes like domestic violence have increased significantly. A rise in commercial burglaries ${ }^{1}$ was observed in New York whereas in New Delhi a decline was observed because of the presence of the police on roads. Furthermore, A decline in crimes like robbery, burglary, larceny, etc. was observed whereas a sharp increase was seen in the cases of domestic violence in both the cities.
\end{abstract}

Keywords: Social distancing, Crime patterns and volume, Crime statistics, Petty crimes

\section{INTRODUCTION}

The world is hit by the novel Coronavirus disease 2019 (COVID-19) caused by severe acute respiratory syndrome coronavirus 2 (SARS-CoV-2). It was first known in Wuhan, China in December 2019 once a cluster of cases of pneumonia of unknown cause were reported to the World Health Organisation (Coronavirus Disease (COVID-

1 Commercial burglary refers to the act or intent of entering some commercial property such as a store, office or similar structure.

Vantage: Journal of Thematic Analysis, 2020; 1(2): 101-112 
19), 2020). Less than a month after the case emerged in China, the virus was carried into different countries by the travellers. By mid- February European countries like Spain and Italy became the epicenter of the virus. As the virus continued to spread across the globe, the World Health Organization announced the COVID-19 outbreak as a pandemic on $11^{\text {th }}$ March 2020.

Following the primary diagnosed case in 2019, there have been more than 9.64 million cases reported across 188 countries and territories, leading to more than 489,000 deaths. However, 4.86 million people have recovered (Aljazeera, 2020).

Coronavirus is a communicable disease that spreads through droplets of saliva or discharge from the nose when an infected person coughs or sneezes. To forestall infection and cut down transmission, individuals are required to take precautions like washing hands regularly, maintaining a distance from each other, refrain from smoking, and avoid unnecessary travel.

The primary concern of any government has been to cut back the strain on healthcare facilities and manage contamination. To prevent community transmissions between individuals, the governments of various countries have adopted certain measures and policies which embrace limiting the big cluster of people coming together, closing public places (cinema halls, malls, schools, universities, workplaces, shops, and markets apart from pharmacies and groceries). International and national movements are restricted with sealed borders and stay at home orders.

While social distancing measures are in practice, they are simultaneously affecting the people in a social, economic, and psychological manner. This has altered the way people interact with one another most of which is now taking place on a virtual platform. Separation from loved ones, the loss of freedom, uncertainty over disease status, and monotony, every so often, will produce dramatic effects (Brooks et al, 2020). The people are experiencing a collective form of trauma due to the rising number of deaths around them, uncertainty regarding employment, loss due to unemployment, health concerns, and false information surfing around social media. Isolation and quarantine have precipitated depression and anxiety (Venkatesh \& Edirappuli, 2020). People who experience these symptoms are more likely to engage in

Vantage: Journal of Thematic Analysis, 2020; 1(2): 101-112 
substance abuse, as there is a 55 percent increase in alcohol sales in the U.S. amid pandemic (Bremner, 2020).

The pandemic has added to the rise of domestic abuse as economic reasons force the victim to remain with their abuser. Some victims who are quarantined with their abusers without access to services are prone to inmate partner violence, child abuse, sexual assault, and rape. It is a pattern being repeated globally where 90 percent of the causes of violence are related to COVID-19 (Connolly et al., 2020). It is also noticed that women even before COVID-19 hesitated to report sexual harassment for various reasons like family honour and shame but the pandemic has worsened the situation for them (Sonkar et al., 2020).

This research paper aims to focus on the type of changes that have occurred within the composition, distribution, and volume of crime post the COVID-19 crisis. We collect crime data of two metropolitan cities - New Delhi and New York to study the concerned issues. We have chosen these cities to account for economic, political, and social differences that exist in these cities that affect crime patterns and volume. The paper develops around the following structure where we provide a theoretical background in section 2, data and methodology in section 3 , results in section 4 , and conclusions in section 5 .

\section{THEORETICAL BACKGROUND}

According to Crime Pattern Theory, crime happens once the activity area of a victim or target intersects with the activity area of an offender. A person's activity space consists of locations in daily life, as an example, home, work, school, shopping areas, entertainment areas, etc (Brantingham \& Brantingham, 2013). Crime is more likely to happen in these spaces as potential offenders look for potential victims at these places because they are generally crowded and convenient for petty crimes like vandalism, shoplifting, break-ins, and pickpocketing.

There is another theory called routine activity theory that focuses on the role of the environment in the occurrence of a crime instead of the characteristics of the offender itself. The routine activity theory was developed by Cohen and Felson in 1979. It is 
based on the premises of the rational choice theory that an agent will maximize his/her utility in the choices they make. It requires the presence of three elements: -
I. A likely offender (motivated)
II. A suitable target
III. The absence of a guardian

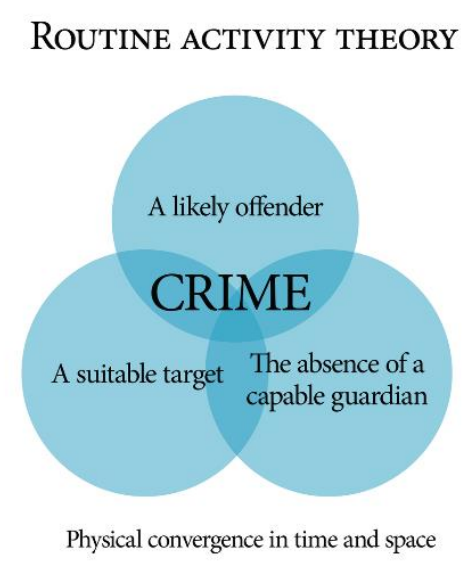

In our case, the lockdown presented the criminal with a changing environment, which altered the way they behaved. This can also explain the major differences between criminal behavior. The presence of police on the streets (guardian) led to the decrease in burglaries in the case of Delhi, while an increase in the same was observed due to the absence of owners (guardian) in the case of New York. Similarly, observing the cases of domestic violence a pattern can be observed where the offender and target were in close proximity without the presence of the guardian. Even though the theory does not explain the motivation behind the commitment of crime it still explains the changes in the behavior (and not the origin of it) (Kitteringham, 2010)

Contamination measures disrupted people's routines and how they interact with each other. While these changes in the pattern of interaction alter opportunities, however, they give rise to new ones. Limiting the large gatherings at public places has reduced the opportunities for potential victims to encounter the potential offender. Thus, we foresee a reduction in the number of assaults with deadly weapons, homicides, robberies, residential burglaries, shoplifting, and thefts as a consequence of a reduced interaction of people in the urban environment. 
But crime is thriving where there is not a barrier between the potential victim and offender, which is a guardian. Cases of domestic violence have escalated as victims are trapped inside with their abusers and are finding it hard to escape. There is a rise in commercial burglaries and motor vehicle theft cases as businesses are left empty because of stay-in orders.

The loss of economic activity due to prolonged lockdown is leading to unemployment and poverty. There have been massive lay-offs by the major companies, small businesses and factories are being shut down leading to the displacement of workers. The greater income inequality, poverty, and job displacement act as a motivation for offenders to commit crimes to sustain themselves.

\section{DATA AND METHODOLOGY}

Secondary data is collected using the electronic resources available on the New York Police Department (NYPD) and Delhi police websites. Crime statistics of New York were divided into two pages; domestic violence and other crimes including larceny, murder, burglary, etc. For New York we collected monthly data for March, April, May, and the first week of June 2020 and its corresponding data in 2019 for the same months. Crime statistics of New Delhi was divided into a crime against women and other categories. The data for the crimes in New Delhi are for the first 6 months (January to June) for both the years 2019 and 2020.

We compare crime data of two major cities of the world, New Delhi and New York. These cities were chosen because both of these cities were severely hit by the COVID19 pandemic and provide public access to police-recorded crime data. Also, the two

cities are very different in terms of governance and cultural norm thereby bringing more dimension to the research. The same factor or event can have different effects on different kinds of crime. For example, social distancing has caused people to stay indoors and has led to an increase in crimes like domestic violence, marital rapes, burglaries in shops, etc. but a decrease in house burglaries, robbery, etc. In Chicago, one of the most violent cities in America drug arrests have plummeted by $42 \%$ in April as the movement is restricted_because of the pandemic. A considerable decrease has 
also been observed in El Salvador, in which one reported one of the highest rates of homicides.

We analyzed the crime statistics of April and May 2020 by observing the percentage increase and decrease in crimes on a monthly basis within the two years under analysis. It allowed us to establish which crime trends have rising or falling tendencies during the pandemic.

Next, we understand the effect of the pandemic in the global economy and foresee an increase in unemployment which is likely to increase minor property crimes as that becomes a source of survival for people with no income.

\section{RESULTS}

\subsection{New York}

One of the major cities of the United States of America, New York was severely hit by the COVID - 19 pandemic like other parts of the world. As of 29 June 2020 New York, registered a total of 413,334 cases out of which 31,340 died due to the disease. By the end of March, a lockdown was imposed in the city bringing almost all the activities to a halt. A change in the environment brought about a significant shift in the crime volumes and rates of the city.

Table 1: Monthly (march-June) Crime Statistics of Newyork for the year 2020

\begin{tabular}{|c|c|c|c|c|}
\hline & March & April & May & June (First Week) \\
\hline Murder & 22 & 31 & 34 & 13 \\
\hline Rape & 99 & 65 & 108 & 67 \\
\hline Robbery & 935 & 679 & 776 & 202 \\
\hline Assault & 1546 & 1130 & 1582 & 971 \\
\hline Burglary & 942 & 1090 & 1154 & 909 \\
\hline Grand Larceny & 2640 & 1566 & 2043 & 467 \\
\hline Grand Larceny Auto & 490 & 560 & 665 & 153 \\
\hline Transit & 173 & 121 & 85 & 28 \\
\hline
\end{tabular}




\begin{tabular}{|c|c|c|c|c|}
\hline Housing & 393 & 299 & 381 & 97 \\
\hline Shooting Incidents & 56 & 56 & 100 & 88 \\
\hline Total & 7296 & 5597 & 6928 & 2995 \\
\hline
\end{tabular}

Source: New York Police Department, https://www.nyc.gov

Table 2: Monthly (march-June) Crime Statistics of Newyork for the year 2019

\begin{tabular}{|c|c|c|c|c|}
\hline & March & April & May & June (First Week) \\
\hline Murder & 21 & 23 & 19 & 5 \\
\hline Rape & 158 & 145 & 163 & 95 \\
\hline Robbery & 888 & 913 & 1088 & 255 \\
\hline Assault & 1664 & 1652 & 1939 & 1392 \\
\hline Burglary & 746 & 828 & 861 & 181 \\
\hline Grand Larceny & 3186 & 3250 & 3608 & 895 \\
\hline Grand Larceny Auto & 303 & 351 & 397 & 92 \\
\hline Transit & 179 & 182 & 203 & 46 \\
\hline Housing & 399 & 442 & 446 & 104 \\
\hline Shooting Incidents & 56 & 62 & 61 & 54 \\
\hline Total & 7600 & 7848 & 8785 & 3120 \\
\hline
\end{tabular}

Source: New York Police Department, https://www.nyc.gov

A percentage decline of $16.5 \%^{2}$ was observed in the overall Crime in 2020 (March to the first week of June) as compared to the corresponding period in 2019. The most significant period of analysis was the months of April and May as this was a time when lockdown began. Overall crime fell by $28.682 \%$ and $21.13 \%{ }^{3}$ in April and May

2 To see the change in overall crime, a sum of total crimes in the year 2019 (March to $1^{\text {st }}$ week of June) and 2020 (march to $1^{\text {st }}$ week of June) have been taken which are 27353 and 22816 respectively. Next, taking the year 2019 as the base, a percentage change has been calculated. We first find the absolute change (22816-27353) and then find the percentage change 16.5 (2281627353/27353 x 100).

3 For the months of April and May, sum of all the crimes as mentioned in the table for the particular months have been taken individually which were 5597 and 6928 respectively for the year 2020 . For 2019, it is 7848 for April and 8785 for May. When we compare Crime rates in New York for the month of April, 2020 with crime rates in April, 2019 we observe crime in 2020 were less by 
respectively. At the same time Murder (including instances of domestic violence) cases increased by $54.761 \%$ in April and May as compared to the same period the previous year. Most of the increase was attributed to the crime of murder due to domestic violence which showed an increase of $75 \%$ contradictory to the overall decrease in the reported cases against Domestic Violence. According to the NYPD, the decrease was most likely due to underreporting by victims due to the lack of access because the abuser spends all their time with them thereby preventing them to call for any sort of help. Also, even though Robbery and Larceny decreased during the lockdown, burglary significantly rose from 1870 cases from April to the first week of June in 2019 to 3153 cases in $2020(+68.60 \%)$ as roads were empty and shops were close making it easy for burglars to break into shops. Surprisingly shooting incidents that decreased in April showed a significant rise in May and June.

\subsection{New Delhi}

One of the strictest and the largest lockdown was imposed in India. The capital city of New Delhi was severely affected by the pandemic and even became a hotspot. Up until June a total of 85,161 confirmed cases have been reported out of which 56,235 were recovered. The effect of the lockdown on the overall crime rate in Delhi has been similar to that of New York. In 2020, a total of 105,676 IPC (The Indian Penal Code is the official criminal code of India. It is a comprehensive code intended to cover all substantive aspects of criminal law (Indian Penal Code, 2020)) crimes were registered till the $31^{\text {st }}$ of May which was $14.61 \%$ less than the total crimes for the same period in 2019.

Table 3: Crime Statistics of Delhi for the year 2019 and 2020 (January to June)

\begin{tabular}{|l|c|c|}
\hline \multicolumn{1}{|c|}{ Crime } & $\mathbf{2 0 1 9}$ & $\mathbf{2 0 2 0}$ \\
\hline Murder & 211 & 203 \\
\hline Rape & 891 & 520 \\
\hline Robbery & 972 & 598 \\
\hline Burglary & 1380 & 755 \\
\hline
\end{tabular}

$28.682 \%$ ((5597 - 7848)/7848x 100). Similarly, Crime in May 2020 were $21.13 \%$ ((6928- 8785)/ 8785 x 100) less than the crimes in May 2019. 


\begin{tabular}{|l|c|c|}
\hline House theft & 1160 & 799 \\
\hline Total & 4614 & 2875 \\
\hline
\end{tabular}

Source: New Delhi police website, https://www.delhipolice.nic.in

Furthermore, a decrease in robbery and burglary was also observed. At a glance, it may look like an opportunity to watch for robbers but the government had deployed the police to make sure that people were not getting out of their houses which resulted in continued police presence on the roads and other public spaces increasing the risk of getting caught, and hence a fall was observed. Also, home burglaries will decrease as people are not leaving their homes empty. Cases of domestic violence have posed a similar gravity as in the case of New York. According to the Delhi Commission for Woman, there was a fall in the number of reported cases on its helpline number 181. In 2019, a total of 8,188 complaints were reported while this year the number of complaints fell to 6,909. During the initial days of the lockdown reporting of cases of domestic violence suddenly reduced and has been gradually increasing as the lockdown is being slowly lifted. This pattern shows that it was only the reporting that reduced during the crime and not the crime itself.

\subsection{Comparing the results obtained from two cities}

- In both these cities, a decrease in the overall crime was observed in the year 2020. However, a deeper look brings out the differences in the way crime has been affected by the pandemic and the lockdown that followed

- Although we observed a rise in the cases of burglary inNew York, Delhi registered a decrease. When we compared the environment in which the criminal had to operate in the above-mentioned cities we found that situations were different. For example, in Delhi heavy police were deployed on roads to make sure that people were abiding by the lockdown measures.

- The cases of domestic violence demonstrated a similar pattern in both regions. A sharp fall in the complaints received from the victims was reported due to the lack of opportunity to make calls etc. due to the continued presence of the perpetrators. 
- While a sharp rise in the cases of murder was observed in New York, Delhi showed a very small change, which can be explained by the fact that the data on murders for Delhi do not involve the cases of death due to domestic violence, which accounted for the $75 \%$ rise in the murder cases in New York.

While it is important to analyze the changes in crime patterns during COVID-19 to understand how to keep it at bay when social distancing norms are being followed it is equally important to understand the after-effects. Experts around the world have predicted that COVID-19 will do serious damage to the world economy. The lockdown has forced businesses and factories around the world to remain closed leading to a supply shock. A lot of companies including Zomato, Uber, etc. have laid-off workers in huge numbers to cover for the losses they have faced leading to a simultaneous demand shock as the loss of jobs will lead to a decrease in the income of people. The International Labor Organization has predicted the job losses to be equivalent to 195 billion and global unemployment is projected to rise by 2.5 million in the year 2020 .

On the demand side, consumer confidence has sharply declined due to fear of unemployment. On the supply side, the continued closure of shops and factories has threatened the livelihoods of a plethora of people, and the resulting loss in income, in turn, reduces demand further.

\section{CONCLUSION}

The conclusion that can be drawn based on the above results is that the rate and crime pattern have been considerably affected by the onset of the COVID-19 pandemic. However, the effect has more to do with the consequences that resulted in changes in the social and economic environment than precisely the pandemic itself. The effect has been analyzed in two different circumstances. First, when lockdown measures were in place to prevent the spread of the disease which brought a change in the environment in which a criminal operates. The effect differed by the pattern and governance policies in different places as well as the nature of the crime. As was seen in the case of New York and New Delhi. A rise in commercial Burglaries was observed in New York whereas in New Delhi a decline was observed because of the presence of the police on roads. Furthermore, A decline in crimes like robbery, burglary, etc. was observed 
whereas a sharp increase was seen in the cases of domestic violence. The overall crime declined, owing to the social distancing measures. Secondly, the effects of the pandemic on the economy and its effect on the crime rates are also analyzed. As predicted by many economists across the world the pandemic has affected businesses globally and is bound to adversely affect the economy which will eventually lead to unemployment and push people towards illegal activities and petty crimes like theft to survive.

\section{CONFLICT OF INTEREST}

We have no conflicts of interest to disclose.

\section{SOURCE OF FUNDING}

NA

\section{ACKNOWLEDGEMENT}

We would like to acknowledge the Centre for Research, Maitreyi College.

\section{REFERENCES}

Brantingham, P \& Brantingham, P. (2013). Crime pattern theory. In R. Wortley, \& L. Mazerolle (Eds.). Environmental Criminology and Crime Analysis. Cullompton, Devon: Willan Publishing, 78-93.

Bremner, J. (2020, April 1). U.S. Alcohol Sales Increase 55 Percent in One Week Amid Coronavirus Pandemic. Newsweek, U.S., Retrieved from https://www.newsweek.com/us-alcohol-sales-increase-55-percent-one-weekamid-coronavirus-pandemic-1495510

Brooks, S. K., Webster, R. K., Smith, L. E., Woodland, L., Wessely, S., Greenberg, N., \& Rubin, G. J. (2020). The psychological impact of quarantine and how to reduce it: rapid review of the evidence. The Lancet, 395(10227), 912-920.

Connolly, K., Jones, S., Phillips, T., Kuo, L., \& Kelly, A. (2020, March 28). Lockdowns around the world bring rise in domestic violence. The Guardian. Retrieved from https://www.theguardian.com/society/2020/mar/28/lockd owns-world-risedomestic-violence . 
Coronavirus: Which countries have confirmed cases? (2020). Aljazeera, Health News. Retrieved from https://www.aljazeera.com/news/2020/01/countries-confirmedcases-coronavirus-200125070959786.html

Kitteringham, G. (2010). Environmental Crime Control. In S. Davies (Ed.). The Professional Protection Officer (1 ${ }^{\text {st }}$ ed.,), Butterworth-Heinemann, 151-160.

Sonkar, M., Soorma, I. \& Akanksha, S. (2020). Can Social Media Mobilise Collective Action for Sexual Violence Against Women?: A Case Study of the '\#MeToo' Movement in the Context of India. Vantage: Journal of Thematic Analysis, 1(1), 66-74.

The Indian Penal Code (Amendment) Bill, 2020. Retrieved from http://164.100.47.4/BillsTexts/RSBillTexts/asintroduced/IPC-E-13320.pdf

Venkatesh, A. \& Edirappuli, S. (2020). Social distancing in COVID-19: what are the mental health implications. The BMJ. Retrieved from https://www.bmj.com/content/369/bmj.m1379

How to cite this article: Arora, P.M., Rao, R. \& Agrawal, S. (2020). Crimes in the Time of COVID-19. Vantage: Journal of Thematic Analysis, 1(2): 101-112.

DOI: https://doi.org/10.52253/vjta.2020.v01i02.07

(C) The Author(s) 2020.

This work is licensed under a Creative Commons Attribution 4.0 International License which permits its use, distribution and reproduction in any medium, provided the original work is cited. 